\title{
INFLUENCE OF COW MANURE AND ITS VERMICOMPOSTING ON THE IMPROVEMENT OF GRAIN YIELD AND QUALITY OF RICE (ORYZA SATIVA L.) IN FIELD CONDITIONS
}

\author{
TAHERI RAHIMABADI, E. ${ }^{1}-$ ANSARI, M. H. ${ }^{1 *}-$ RAZAVI NEMATOLLAHI, A. ${ }^{2}$ \\ ${ }^{I}$ Department of Agronomy and Plant Breeding, Rasht Branch, Islamic Azad University \\ Rasht, Iran \\ ${ }^{2}$ Department of Plant Pathology, Rasht Branch, Islamic Azad University \\ Rasht, Iran \\ *Corresponding author \\ e-mail:Ansary330@gmail.com,Ansari@iaurasht.ac.ir \\ (phone: +98-914-454-4931) \\ (Received 22 $2^{\text {nd }}$ Jul 2017; accepted $27^{\text {th }}$ Oct 2017)
}

\begin{abstract}
A field experiment was conducted to assess the impact of cow manure and its vermicompost on the improvement of rice grain yield and quality in Rasht, Iran in 2015 and 2016. The experimental factors were devoted to cow manure $\left(0,10\right.$ and $\left.20 \mathrm{t} \mathrm{ha}^{-1}\right)$ and vermicompost $\left(0,5\right.$ and $\left.10 \mathrm{tha}^{-1}\right)$. The results revealed that the application of cow manure and vermicompost increased leaf chlorophyll and grain yield components such as the number of fertile tillers and the number of grain, but, it decreased by 1000-grain weight. The highest grain yield was obtained from the application of $30 \mathrm{tha}^{-1}$ cow manure $+10 \mathrm{tha}^{-1}$ vermicompost in the first year $\left(3537 \mathrm{~kg} \mathrm{ha}^{-1}\right)$ and in the second year $\left(3958 \mathrm{~kg} \mathrm{ha}^{-1}\right)$. In addition, the application of cow manure and vermicompost increased the grain's N, P and K content by 8-20\%, 22$23 \%$ and $20-33 \%$, but decreased the starch content by $3-7 \%$. Although the combined application of various rates of cow manure and vermicompost improved plant growth and nutrient uptake, the influence of vermicompost on the grain yield and quality of gain was much stronger. In poor areas of the world that experience reduction in rice yield mainly due to lack of soil organic matter, and the farmers cannot buy vermicompost to improve soil fertility, we recommend the combined application of manure and vermicompost, which leads to increased grain qualitative traits and milling percentage, resulting in higher nutritional value of grains and higher grain yield.
\end{abstract}

Keywords: biological yield, chlorophyll, nutrient uptake, protein, starch

\section{Introduction}

Rice is a global grain that is grown in about 89 nations and it is a stable food for more than half of the global population (Bodh and Rai, 2015). For many years, rice has been supporting more people than any other cereal. Rice is one of the three most important food crops in Iran (Toorminaee et al., 2017). Fertilizers are the major source of nutrients for rice under intensive cultivation. The use of chemical fertilizers in rice cultivation potentially reduces soil fertility (Biswas et al., 2017). The use of P and K fertilizers in rice cultivation may in the long run lead to nutrient imbalance in the soil, resulting in lower rice productivity (Dong et al., 2012). To improve physical, chemical and biological properties of soil, organic fertilizer can be applied (Mengi et al., 2016). Several studies have shown that the regular application of organic fertilizer, especially manure, could increase the soil org-P fraction (Pant et al., 2009), the availability of C and soil microbial activity and soil organic matter (Dixit and Gupta, 2000), N use efficiency and rice yield (Zhou et al., 2016). Manures of the animals contain valuable 
nutrients and organic compounds that can restore degraded soils and ensure sustainable long-term agricultural activity (Lalandera et al., 2015). Properly treating the organic waste fraction reduces the environmental impact by avoiding greenhouse gas emissions from landfills (Joshi et al., 2015) and decreasing/avoiding the need for chemical fertilizer (Xu et al., 2008). Among the various types of animal waste, the amount of cow manure is 4-9 times than that of pig manure (Guo et al., 2013). Hence, investigating effective measures for disposing of animal waste, especially cow manure, has become an important topic. To this end, earthworms have been widely used to recycle animal manures to vermicompost, thereby rendering the manure harmless. Compared with raw manure materials and its traditional compost, vermicompost possesses a greater capacity for cation exchange and a larger surface area, etc (Lalandera et al., 2015; Meier et al., 2017). Among the various types of animal waste, the amount of cow manure is 4-9 times than that of pig manure (Guo et al., 2013). Hence, investigating effective measures for disposing of animal waste, especially cow manure, has become an important topic. To this end, earthworms have been widely used to recycle animal manures to vermicompost, thereby rendering the manure harmless. Compared with raw manure materials and its traditional compost, vermicompost possesses a greater capacity for cation exchange and a larger surface area, etc. (Meier et al., 2017). Bejbaruah et al. (2013) and Mengi et al. (2016) explored rice response to various rates of compost and animal manure and reported that the application of manure and compost significantly enhanced plant height, tiller number per plant, spike length, and grain and straw yield of rice as compared to control. They related these enhancements to the improvement of soil physical and chemical features and higher availability of nutrients due to the application of organic fertilizers.

In Iran, 20 million tons of manure is produced by animals per annum. The rate of vermicompost production is negligible compared to cow manure. Efforts have been taken in recent years to produce more vermicompost, but its application in farms, especially in rice farms, has not been increased remarkably (Rezaei, 2013). There are some quantitative reports on the application of the mixture of cow manure and vermicompost on grains under field conditions. The present experiment is based on the premise that the application of cow vermicompost will not only improve the grain yield, but also the grain quality of rice from the crop nutritional and marketable viewpoints, as compared to cow manure. Therefore, leaf chlorophyll and grain yield, protein, and NPK uptake were measured to assess this hypothesis.

\section{Materials and methods}

\section{Experimental site and plant growth conditions}

The field experiment was conducted on clay-loam soil at the Agricultural Research Farm of Islamic Azad University, Rasht, Guilan province, Iran in 2015 and 2016. The area is located at $37^{\circ} 22 \mathrm{~N}$ latitude and $49^{\circ} 63 \mathrm{E}$ longitude and $15 \mathrm{~m}$ above the sea level. To simplify the comparison of the growing season weather, we considered the monthly total precipitation and temperature from May through August at the Rasht Agricultural Research Farm (Figure 1). 

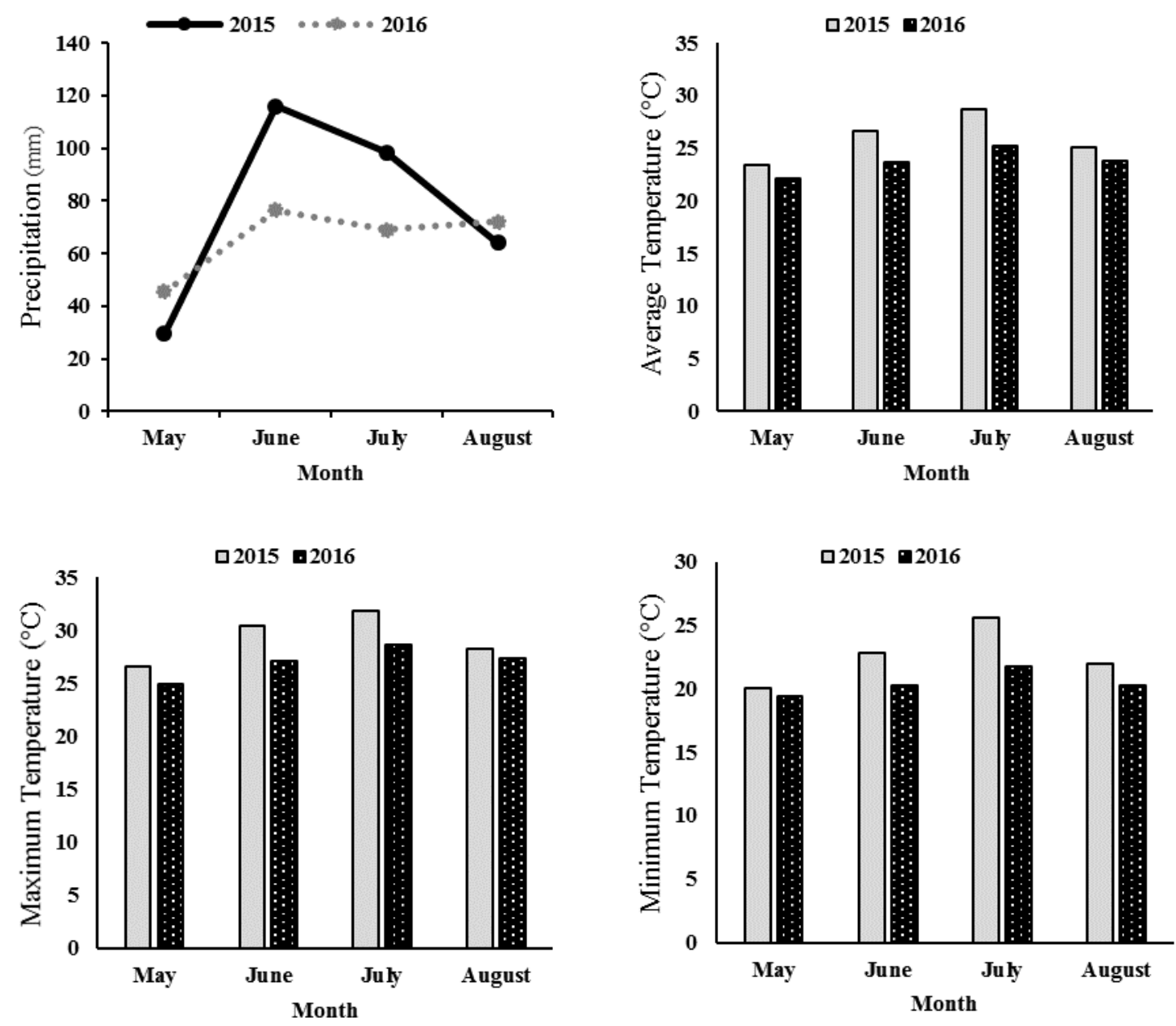

Figure 1. Monthly precipitation and temperature from May to August for the growing season (2015-2016) at the Rasht Agricultural Research Farm, Iran.

In order to determine soil characteristics, soil sampling was performed before the experiment. To do this, field soil sampling was done from the depth of 0-30 and 30-60 $\mathrm{cm}$ in eight spots. Then the collected samples sent to the laboratory in order to determine soil texture and the chemical composition. Properties of experimental soil samples are given in Table 1.

Table 1. Soil Physical and chemical characteristics of the soil during the two-year study.

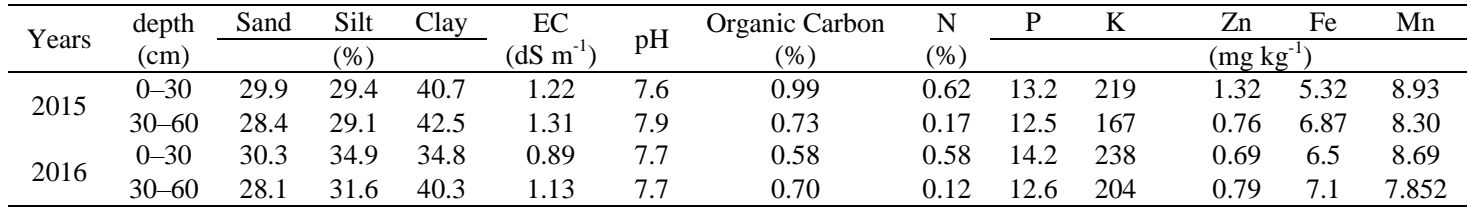




\section{Preparation and applied of Vermicompost}

Cow manure, consisting of a mixture of faeces, urine and straw was obtained from the agricultural cow complex Sepidar, in Rasht, Iran. Vermicomposting was carried out in a $3 \mathrm{~m}^{3}$ vermireactor containing a stable and very active population of the earthworm Eisenia andrei. The reactor was fed with different animal manures and mixed agricultural wastes, and supported a population density of $250 \mathrm{~g}$ of earthworms $\mathrm{kg}^{-1}$ in the top layers. The upper surface of the vermireactor was divided into four independent compartments and $45 \mathrm{~kg}$ of cow manure were placed in three successive layers $(15 \mathrm{~kg}$ each) added to each compartment as the waste was processed by the earthworms. The moisture content of the cow manure in the vermireactor was maintained at 75-80\% and the sample was collected from the last layer (40 days of earthworm processing) of the reactor once the manure was processed by the earthworms (Lazcano et al., 2008).

Vermicomposting process significantly changed the physical and chemical properties of cow manure. The vermicompost was much darker in color, had good esthetics and processed into a homogeneous compound after earthworm activity. The total content of waste mixture was reduced 1.8-2.7 times after vermicomposting. The vermicomposting process significantly helps in abatement of organic matter pollution load in the environment and soil. The physicochemical traits and nutrient status of cow manure and its vermicompost are given in Table 2.

Cow manure and its vermicompost were applied at 20 days before transplanting. In control plot, the nutritional requirements were supplied by chemical fertilizers in accordance with the results of soil analysis.

Table 2. Physicochemical properties and elemental composition of the cow manure and its vermicompost as well as their detection method.

\begin{tabular}{llll}
\hline Parameter* & Method & Cow manure & Vermicompost \\
\hline $\mathrm{pH}$ & pH meter & $8.10 \pm 0.13$ & $7.43 \pm 0.06$ \\
$\mathrm{EC}$ & Conductometer & $1.08 \pm 0.01$ & $1.26 \pm 0.03$ \\
Ash content $\left(\mathrm{g} \mathrm{kg}^{-1}\right)$ & Burning & $197 \pm 10.3$ & $441 \pm 21.7$ \\
Total OC $\left(\mathrm{g} \mathrm{kg}^{-1}\right)$ & Walkley black & $412 \pm 16.9$ & $316 \pm 6.5$ \\
Total OM (\%) & Nitration & $78.6 \pm 2.3$ & $49 \pm 4.3$ \\
Total N $\left(\mathrm{g} \mathrm{kg}^{-1}\right)$ & Kjeldahl & $16.8 \pm 0.51$ & $28.3 \pm 1.54$ \\
Total P $\left(\mathrm{g} \mathrm{kg}^{-1}\right)$ & Olsen & $6.4 \pm 0.91$ & $13.4 \pm 0.84$ \\
Total K $\left(\mathrm{g} \mathrm{kg}^{-1}\right)$ & Film photometry & $9.4 \pm 1.02$ & $13.7 \pm 1.11$ \\
$\mathrm{C}: \mathrm{N}$ & - & $24.46 \pm 2.3$ & $11.3 \pm 0.47$ \\
$\mathrm{Cu}\left(\mathrm{mg} \mathrm{kg}^{-1}\right)$ & Atomic & $135.2 \pm 7.92$ & $164.8 \pm 13.8$ \\
$\mathrm{Fe}\left(\mathrm{mg} \mathrm{kg}^{-1}\right)$ & Atomic & $215.4 \pm 5.8$ & $496.6 \pm 5.7$ \\
$\mathrm{Mn}\left(\mathrm{mg} \mathrm{kg}^{-1}\right)$ & Atomic & $109.7 \pm 11.4$ & $248.7 \pm 4.6$ \\
$\mathrm{Zn}\left(\mathrm{mg} \mathrm{kg}^{-1}\right)$ & Atomic & $184 \pm 9.83$ & $369 \pm 12.06$ \\
\hline
\end{tabular}

*Dry matter basis

\section{Sowing condition}

Rice seeds ('Hashemi'cultivar) were disinfected with 70\% thiophanate-methyl WP

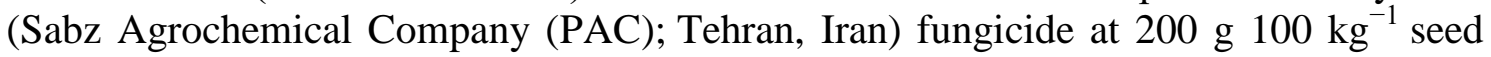
and were then sown in the nursery. The seedlings were manually transplanted in the experimental field at the 2-3 leaf stage at a spacing of $25 \times 25 \mathrm{~cm}^{2}$. Weeds were 
controlled by hand weeding during the growth season. The permanent flood water level was maintained at $10 \mathrm{~cm}$ during the rice growing period.

\section{Plant sampling}

At the soft dough stage, eight randomly chosen plants were removed from each plot and in the flag leaves, chlorophyll were determined by Arnon (1949) method. At maturity stage, rice grain yield (based on $14 \%$ humidity) was determined from $2.5 \mathrm{~m}^{2}$ per plot. Moisture content of grains was measured using a digital grain moisture meter (Model GMK- 303R5-Korea) and grain yield per plot was calculated as ((100 moisture content of the sample) $\times$ fresh grain weight) $/ 86$ to convert the sample to $14 \%$ moisture content. Yield components, that is, number of tiller, number of filled grains and 1000-grain weight, were determined from 12 plants (excluding the border ones) sampled randomly from each plot. To determine aboveground biomass, a $1 \mathrm{~m}^{2}$ sample from each plot was randomly chosen and placed in a separate paper bag, dried at $72{ }^{\circ} \mathrm{C}$ for $48 \mathrm{~h}$, weighed, and expressed as the biological yield (dry weight of above-ground plant) per hectare. Harvest index was the proportion (percentage) of filled grain weight to biological yield.

For measuring grain $\mathrm{N}$ concentration, rice grains were grounded to pass through a 1$\mathrm{mm}$ sieve. $\mathrm{N}, \mathrm{P}$ and $\mathrm{K}$ concentration was determined using micro-Kjeldahl, vanadomolybdate and flame photometry, respectively (Emami, 1996) and were expressed as the percent of grain dry weight. N, P and K uptake in grain was calculated by multiplying grain dry weight by grain $\mathrm{N}$ concentration. Grain protein concentration was calculated as $6.25 \times$ nitrogen content measured by the micro Kjeldahl technique. Similarly grain starch percentage (Amylase) activity is done by using anthrone reagent as suggested by Reyes et al. (1965).

Paddy samples for milling quality evaluation were harvested from the $2.5 \mathrm{~m}^{2}$ per plot, threshed by a simple motorized thresher and dried up to $8 \%$, wet basis (w.b.) using the laboratory dryer (Memmart Model 600, Germany) set at $45{ }^{\circ} \mathrm{C}$. Paddy moisture content was determined using the digital grain moisture meter (Model GMK-303R5-Korea). After drying process, $200 \mathrm{~g}$ of dried paddy from each treatment were dehulled by a laboratory rubber roll huller (SATAKE Co. Ltd, Japan) and then was milled using a laboratory rice whitener (McGill Miller, USA). The milling percentage was calculated by using the following formula and presented in percentage (Zhao and Fitzgerald, 2013):

$$
\text { Milling }(\%)=\frac{\text { Total weight of milled rice }(\mathrm{g})}{\text { Total weight of rough rice with usk }} \times 100
$$

It should be noted that vermicompost and cow manure in the second year were used as the first year and all the works done in the first year in the second year were repeated.

\section{Experimental design and statistical analysis}

The experiments were carried out in a factorial trial based on randomized complete block design (RCBD) with 3 replications. Experimental factors included vermicompost $\left(\mathrm{V} 0=0, \mathrm{~V} 1=5\right.$ and $\left.\mathrm{V} 2=10 \mathrm{tha}^{-1}\right)$ and cow manure $(\mathrm{M} 0=0, \mathrm{M} 1=10$, and $\mathrm{M} 2=20 \mathrm{t} \mathrm{ha}^{-1}$ ). 
Basically, various levels of manure and vermicompost as independent variable and measured characters such as seed yield, biologic yield, tiller number, seed number, leaf chlorophyll and the content of nitrogen, potassium and phosphorus as dependent variable were contemplated. In the meantime, plants harvested from $1 \mathrm{~m}^{2}$ of each plot included experimental samples to measure the mentioned above characters.

All data were subjected to analysis of variance (ANOVA) using SAS 9.3 software. When $\mathrm{F}$ test indicated statistical significance at $\mathrm{P}<0.01$ or $\mathrm{P}<0.05$, the least significant difference (LSD) was used to separate the means.

\section{Results}

\section{Leaf chlorophyll}

According to the results of ANOVA, the interaction effect of vermicompost $\times$ cow manure $\times$ year had significant impact on the chlorophyll $a+b$ at the $5 \%$ probability level. Means comparison revealed that at vermicompost rates of 0 and $5 \mathrm{t} \mathrm{ha}^{-1}$, the chlorophyll was increased with cow manure, but at vermicompost rate of $10 \mathrm{t} \mathrm{ha}^{-1}, 20$ $\mathrm{t} \mathrm{ha} \mathrm{a}^{-1}$ cow manure in the first year was the only treatment that increased the chlorophyll $a+b$ as compared to no cow manure application. It did not result in significant differences in the second year (Table 3).

\section{Tiller number, 1000-grain weight, grain number}

The interaction effect of vermicompost $\times$ cow manure had significant impact on the number of tillers per hill, the 1000-grain weight, and the number of grains per panicle in both years. The application of cow manure and vermicompost, both as a mixture or individually, increased the number of tillers per hill and the number of grains per panicle as compared to the control, but vermicompost had a stronger influence on increasing these two traits so that the application of vermicompost in addition to cow manure further enhanced the number of tillers and the number of grains per panicle than the control. The highest number of tillers and the highest number of grains per panicle were observed in $\mathrm{M}_{2} \mathrm{~V}_{2}$, so that the tiller number was $22.36 \%$ higher in the first year and $27.32 \%$ higher in the second year than the control, and the number of grains per panicle in the first and second years was 81.22 and $61.52 \%$ higher than the control, respectively. However, the application of cow manure and vermicompost reduced the 1000-grain weight as compared to the control (Table 3).

\section{Harvest index, grain yield and biological yield}

The interaction effect of vermicompost $\times$ cow manure $\times$ year had significant impact on the harvest index, the grain yield, and the biological yield. According to means comparison, 10 and $20 \mathrm{tha}^{-1}$ cow manure improved the biological yield by 5.3 and $8.1 \%$ in the first year and by 4.3 and $18.1 \%$ in the second year as compared to the control, respectively. Also, the application of 5 and $10 \mathrm{t} \mathrm{ha}^{-1}$ vermicompost increased it by 9.0 and $17.9 \%$ in the first year and 12.3 and $24.8 \%$ in the second year, respectively. Likewise, the grain yield showed an 11.26 and $52.66 \%$ increase in the first year and a 36.1 and $61.2 \%$ increase in the second year when 10 and $20 \mathrm{t} \mathrm{ha}^{-1}$ cow manure was incorporated, respectively. The application of vermicompost at the rates of 5 and 10 $\mathrm{t} \mathrm{ha}^{-1}$ increased grain yield by 41.4 and $69.6 \%$ in the first year and by 49.2 and $93.0 \%$ in the second year, respectively. The highest grain yield $\left(3537 \mathrm{~kg} \mathrm{ha}^{-1}\right.$ in the first year and 
$3958 \mathrm{~kg} \mathrm{ha}^{-1}$ in the second year) was obtained from $\mathrm{M}_{2} \mathrm{~V}_{2}$. The highest harvest index was observed in $\mathrm{M}_{1} \mathrm{~V}_{1}$ in the first year and in $\mathrm{M}_{1} \mathrm{~V}_{2}$ in the second year (Table 4).

Table 3. Mean comparison of cow manure and its vermicompost interaction effect on tiller number, 1000 - grain weight, number of filled grain, grain yield, biological yield and harvest index in 2015 and 2016.

\begin{tabular}{|c|c|c|c|c|c|c|c|}
\hline \multirow[t]{2}{*}{$\mathrm{M} \times \mathrm{V}$} & \multicolumn{7}{|c|}{2015} \\
\hline & $\begin{array}{l}\text { chlorophyll } \\
\mathrm{a}+\mathrm{b}\end{array}$ & $\begin{array}{l}\text { Tiller number } \\
\text { in hill }\end{array}$ & $\begin{array}{l}1000 \text { - grain } \\
\text { Weight }(\mathrm{g})\end{array}$ & $\begin{array}{l}\text { Number of } \\
\text { filled grain }\end{array}$ & $\begin{array}{l}\text { Seed yield } \\
\left(\mathrm{kg} \mathrm{ha}^{-1}\right)\end{array}$ & $\begin{array}{l}\text { Biological } \\
\text { yield } \\
\left(\mathrm{kg} \mathrm{ha}^{-1}\right)\end{array}$ & $\begin{array}{l}\text { Harvest Index } \\
(\%)\end{array}$ \\
\hline V0M0 & $2.35 \mathrm{e}$ & $56.66 \mathrm{c}$ & $26.26 \mathrm{a}$ & $64.64 \mathrm{e}$ & $1754 \mathrm{~d}$ & $5283 \mathrm{e}$ & $35.0 \mathrm{c}$ \\
\hline V0M1 & $3.67 \mathrm{~d}$ & $59.73 \mathrm{bc}$ & $23.56 \mathrm{e}$ & $74.96 \mathrm{de}$ & $1958 \mathrm{~d}$ & 5566 e & $35.1 \mathrm{c}$ \\
\hline V0M2 & $4.46 \mathrm{c}$ & $61.63 \mathrm{bc}$ & $25.43 \mathrm{c}$ & $84.56 \mathrm{cde}$ & $2616 b c$ & $5716 \mathrm{de}$ & $45.7 \mathrm{a}$ \\
\hline V1M0 & $4.79 \mathrm{bc}$ & $60.33 \mathrm{bc}$ & $24.43 \mathrm{~d}$ & $94.72 \mathrm{~cd}$ & $2400 \mathrm{~cd}$ & $5862 \mathrm{de}$ & $41.6 \mathrm{~b}$ \\
\hline V1M1 & $3.36 \mathrm{~d}$ & $63.33 \mathrm{abc}$ & $23.23 \mathrm{e}$ & $110.6 \mathrm{ab}$ & $2825 \mathrm{abc}$ & $5737 \mathrm{de}$ & $48.4 \mathrm{a}$ \\
\hline $\mathrm{V} 1 \mathrm{M} 2$ & $4.55 \mathrm{bc}$ & $63.65 \mathrm{abc}$ & $25.63 \mathrm{bc}$ & $91.3 \mathrm{~cd}$ & $2895 \mathrm{abc}$ & $6858 \mathrm{bc}$ & $42.2 \mathrm{~b}$ \\
\hline $\mathrm{V} 2 \mathrm{M} 0$ & $4.39 \mathrm{c}$ & $62.33 \mathrm{abc}$ & $25.73 \mathrm{abc}$ & $93.3 \mathrm{~cd}$ & $2666 \mathrm{bc}$ & $6229 \mathrm{~cd}$ & $42.8 \mathrm{~b}$ \\
\hline V2M1 & $5.23 \mathrm{~b}$ & $64.33 \mathrm{ab}$ & $26.16 \mathrm{ab}$ & $98.0 \mathrm{~b}$ & $3312 \mathrm{ab}$ & $7075 \mathrm{ab}$ & $46.8 \mathrm{a}$ \\
\hline V2M2 & $6.57 \mathrm{a}$ & $69.33 \mathrm{a}$ & $23.63 \mathrm{e}$ & $122.9 \mathrm{a}$ & $3537 \mathrm{a}$ & $7670 \mathrm{a}$ & $46.1 \mathrm{a}$ \\
\hline \multirow[t]{2}{*}{$\operatorname{LSD}(0.05)$} & 0.72 & 7.19 & 0.589 & 20.8 & 851 & 637 & 2.88 \\
\hline & \multicolumn{7}{|c|}{2016} \\
\hline V0M0 & $5.61 \mathrm{~cd}$ & $64.66 \mathrm{e}$ & $25.06 \mathrm{a}$ & $87.12 \mathrm{e}$ & $2208 \mathrm{e}$ & $7275 \mathrm{c}$ & $30.8 \mathrm{~d}$ \\
\hline V0M1 & $7.12 \mathrm{bc}$ & 70.33 cde & $25.46 \mathrm{a}$ & $97.6 \mathrm{~cd}$ & $2879 \mathrm{~d}$ & $7166 \mathrm{c}$ & $38.5 \mathrm{a}$ \\
\hline V0M2 & $8.43 \mathrm{ab}$ & $72.33 \mathrm{~cd}$ & $25.50 \mathrm{a}$ & $111.4 \mathrm{bcd}$ & $3012 \mathrm{~cd}$ & $8470 \mathrm{~b}$ & $35.5 \mathrm{bc}$ \\
\hline V1M0 & $4.59 \mathrm{~d}$ & $67.33 \mathrm{de}$ & $23.36 \mathrm{bc}$ & $107.8 \mathrm{bcd}$ & $2937 \mathrm{~cd}$ & $8250 \mathrm{bc}$ & $36.4 \mathrm{~b}$ \\
\hline V1M1 & $5.65 \mathrm{~cd}$ & $74.66 \mathrm{bc}$ & $23.40 \mathrm{bc}$ & $109.7 \mathrm{bcd}$ & $3150 \mathrm{bcd}$ & $8641 \mathrm{~b}$ & $36.4 \mathrm{~b}$ \\
\hline V1M2 & $6.70 \mathrm{c}$ & $75.66 \mathrm{bc}$ & $22.53 \mathrm{c}$ & $105.8 \mathrm{bcd}$ & $3516 a b c$ & $9016 \mathrm{~b}$ & $39.0 \mathrm{a}$ \\
\hline V2M0 & $8.52 \mathrm{a}$ & $73.00 \mathrm{~cd}$ & $25.63 \mathrm{a}$ & $112.9 \mathrm{bc}$ & 3429 abcd & 8945 b & $38.3 \mathrm{a}$ \\
\hline V2M1 & $8.87 \mathrm{a}$ & $80.66 \mathrm{ab}$ & $23.43 \mathrm{~b}$ & $128.6 \mathrm{ab}$ & $3708 \mathrm{ab}$ & $10895 \mathrm{a}$ & $34.0 \mathrm{c}$ \\
\hline V2M2 & $9.66 \mathrm{a}$ & $82.33 \mathrm{a}$ & $23.53 \mathrm{~b}$ & $140.7 \mathrm{a}$ & 3958 a & 10979 a & $36.0 \mathrm{~b}$ \\
\hline \multirow[t]{2}{*}{$\operatorname{LSD}(0.05)$} & 1.52 & 6.543 & 0.872 & 24.5 & 585 & 1121 & 1.33 \\
\hline & \multicolumn{7}{|c|}{$F$ value } \\
\hline $\mathrm{Y} \times \mathrm{M} \times \mathrm{V}$ & $2.76^{*}$ & $5.61 * *$ & $24.12 * *$ & $7.70 * *$ & $6.48 * *$ & $8.92 * *$ & $6.12 * *$ \\
\hline CV $(\%)$ & 11.8 & 5.85 & 1.75 & 12.84 & 14.4 & 6.99 & 16.21 \\
\hline
\end{tabular}

Different letters in the same column indicate significant differences by LSD test $(\mathrm{p}<0.05) .\left(\mathrm{V}_{0}, \mathrm{~V}_{1}\right.$ and $\mathrm{V}_{2}: 0,5$ and $10 \mathrm{t} \mathrm{ha}^{-1}$ vermicompost, respectively; $\mathrm{M}_{0}, \mathrm{M}_{1}$ and $\mathrm{M}_{2}: 0,15$ and $30 \mathrm{t} \mathrm{ha}^{-1}$ cow manure, respectively).

*, ** Significant at $\mathrm{p}<0.05$ and $\mathrm{p}<0.01$, respectively. Y: Year, V: Vermicompost, M: Cow manure and CV: Coefficient of Variation.

\section{NPK concentration and uptake by grains}

The concentration and uptake of the elements were changed significantly under the interaction effect of vermicompost $\times$ cow manure $\times$ year. When $10 \mathrm{tha}^{-1}$ vermicompost and $20 \mathrm{t} \mathrm{ha}^{-1}$ cow manure were applied individually, $\mathrm{N}, \mathrm{P}$ and $\mathrm{K}$ concentrations of the rice grains showed improvements in both years, but the maximum concentrations were obtained when $20 \mathrm{tha}^{-1}$ cow manure $+10 \mathrm{t} \mathrm{ha}^{-1}$ vermicompost were applied so that this treatment increased $\mathrm{N}$ concentrations from $1.34 \%$ to $2.02 \%$ in the first year and from $1.35 \%$ to $2.35 \%$ in the second year, $\mathrm{K}$ concentration from $0.28 \%$ to $0.78 \%$ in the first year and from $0.266 \%$ to $0.750 \%$ in the second year, and P concentration from $0.190 \%$ to $0.375 \%$ in the first year and from $0.186 \%$ to $0.355 \%$ in the second year. The uptake rate of $\mathrm{N}, \mathrm{P}$, and $\mathrm{K}$ by grains was also increased with cow manure and vermicompost rates (although some treatments did not exhibit significant differences with the control) so that 
plants fertilized with $10 \mathrm{tha}^{-1}$ vermicompost $+20 \mathrm{tha}^{-1}$ cow manure resulted in higher uptake rate of the nutrients as compared to other organic fertilizer treatments (Table 4).

Table 4. Mean comparison of cow manure and its vermicompost interaction effect on $N, P$ and $K$ concentration and their uptake by rice grain.

\begin{tabular}{|c|c|c|c|c|c|c|}
\hline \multirow[b]{2}{*}{$\mathrm{M} \times \mathrm{V}$} & \multicolumn{5}{|c|}{2015} & \multirow[b]{2}{*}{$\begin{array}{l}\text { N uptake } \\
\left(\mathrm{kg} \mathrm{ha}^{-1}\right)\end{array}$} \\
\hline & $\begin{array}{c}\mathrm{K} \\
\text { concentration } \\
(\%)\end{array}$ & $\begin{array}{c}\mathrm{P} \\
\text { concentration } \\
(\%)\end{array}$ & $\begin{array}{c}\mathrm{N} \\
\text { concentration } \\
(\%)\end{array}$ & $\begin{array}{l}\text { K uptake } \\
\left(\mathrm{kg} \mathrm{ha}^{-1}\right)\end{array}$ & $\begin{array}{l}\text { P uptake } \\
\left(\mathrm{kg} \mathrm{ha}^{-1}\right)\end{array}$ & \\
\hline V0M0 & $0.280 \mathrm{c}$ & $0.190 \mathrm{e}$ & $1.680 \mathrm{ab}$ & $24.58 \mathrm{a}$ & $14.01 \mathrm{a}$ & $55.65 \mathrm{ab}$ \\
\hline V0M1 & $0.420 \mathrm{bc}$ & $0.300 \mathrm{bc}$ & $1.340 \mathrm{~b}$ & $7.72 \mathrm{c}$ & $8.27 \mathrm{bc}$ & $23.56 \mathrm{~g}$ \\
\hline V0M2 & $0.500 \mathrm{bc}$ & $0.300 \mathrm{bc}$ & $1.676 \mathrm{ab}$ & $19.47 \mathrm{ab}$ & $12.66 \mathrm{a}$ & $52.08 \mathrm{bc}$ \\
\hline V1M0 & $0.490 \mathrm{bc}$ & $0.232 \mathrm{de}$ & $1.676 \mathrm{ab}$ & $28.21 \mathrm{a}$ & $13.56 \mathrm{a}$ & $43.76 \mathrm{~d}$ \\
\hline V1M1 & $0.400 \mathrm{bc}$ & $0.232 \mathrm{de}$ & $2.023 \mathrm{a}$ & $10.61 \mathrm{bc}$ & $6.17 \mathrm{c}$ & 34.99 ef \\
\hline V1M2 & $0.500 \mathrm{bc}$ & $0.325 \mathrm{ab}$ & $1.700 \mathrm{ab}$ & $18.33 \mathrm{abc}$ & $11.00 \mathrm{ab}$ & $45.33 \mathrm{~cd}$ \\
\hline V2M0 & $0.570 \mathrm{ab}$ & $0.262 \mathrm{~cd}$ & $1.340 \mathrm{~b}$ & $19.38 \mathrm{ab}$ & 8.92 bc & $32.16 \mathrm{f}$ \\
\hline V2M1 & $0.570 \mathrm{ab}$ & $0.325 \mathrm{ab}$ & $1.343 \mathrm{~b}$ & $18.74 \mathrm{ab}$ & 8.89 bc & $41.86 \mathrm{de}$ \\
\hline V2M2 & $0.780 \mathrm{a}$ & $0.375 \mathrm{a}$ & $1.700 \mathrm{ab}$ & $19.65 \mathrm{ab}$ & $8.31 \mathrm{bc}$ & $60.13 \mathrm{a}$ \\
\hline $\operatorname{LSD}(0.05)$ & 0.230 & 0.057 & 0.577 & 10.67 & 3.39 & 7.37 \\
\hline \multicolumn{7}{|c|}{2016} \\
\hline V0M0 & $0.350 \mathrm{~d}$ & $0.186 \mathrm{~d}$ & $2.350 \mathrm{a}$ & $9.62 \mathrm{~d}$ & $5.77 \mathrm{~d}$ & $51.89 \mathrm{bc}$ \\
\hline V0M1 & $0.600 \mathrm{~b}$ & $0.250 \mathrm{c}$ & $1.680 \mathrm{~d}$ & $23.27 \mathrm{bc}$ & $12.60 \mathrm{~b}$ & $48.37 \mathrm{~cd}$ \\
\hline V0M2 & $0.600 \mathrm{~b}$ & $0.187 \mathrm{~d}$ & $1.690 \mathrm{c}$ & $26.57 \mathrm{~b}$ & $8.30 \mathrm{~cd}$ & $57.95 \mathrm{~b}$ \\
\hline V1M0 & $0.266 \mathrm{e}$ & $0.262 \mathrm{c}$ & $1.400 \mathrm{e}$ & $7.08 \mathrm{~d}$ & $11.22 \mathrm{~b}$ & $41.12 \mathrm{~d}$ \\
\hline V1M1 & $0.470 \mathrm{c}$ & $0.300 \mathrm{abc}$ & $1.350 \mathrm{f}$ & $18.85 \mathrm{c}$ & $12.03 \mathrm{~b}$ & $40.66 \mathrm{~d}$ \\
\hline V1M2 & $0.750 \mathrm{a}$ & $0.285 \mathrm{bc}$ & $1.350 \mathrm{f}$ & $24.01 \mathrm{bc}$ & $17.60 \mathrm{a}$ & $53.43 \mathrm{bc}$ \\
\hline V2M0 & $0.580 \mathrm{bc}$ & $0.262 \mathrm{c}$ & $1.350 \mathrm{f}$ & $26.19 \mathrm{~b}$ & $11.85 \mathrm{~b}$ & $47.47 \mathrm{~cd}$ \\
\hline V2M1 & $0.580 \mathrm{bc}$ & $0.325 \mathrm{ab}$ & $2.010 \mathrm{~b}$ & $27.30 \mathrm{~b}$ & $12.35 \mathrm{~b}$ & $74.53 \mathrm{a}$ \\
\hline V2M2 & $0.575 b c$ & $0.355 \mathrm{a}$ & $1.690 \mathrm{c}$ & $37.18 \mathrm{a}$ & $10.30 \mathrm{bc}$ & $53.23 \mathrm{bc}$ \\
\hline $\operatorname{LSD}(0.05)$ & 0.0854 & 0.0577 & 0.0026 & 5.9952 & 2.5893 & 7.9604 \\
\hline \multicolumn{7}{|c|}{$F$ value } \\
\hline $\mathrm{Y} \times \mathrm{M} \times \mathrm{V}$ & $6.18 * *$ & $4.90 * *$ & $3.29 *$ & $8.19 * *$ & $7.05^{* *}$ & $11.38 * *$ \\
\hline CV (\%) & 20.7 & 12.14 & 14.45 & 24.54 & 16.19 & 9.29 \\
\hline
\end{tabular}

Different letters in the same column indicate significant differences by LSD test $(\mathrm{p}<0.05) .\left(\mathrm{V}_{0}, \mathrm{~V}_{1}\right.$ and $\mathrm{V}_{2}: 0,5$ and $10 \mathrm{tha}^{-1}$ vermicompost, respectively; $\mathrm{M}_{0}, \mathrm{M}_{1}$ and $\mathrm{M}_{2}: 0,15$ and $30 \mathrm{tha} \mathrm{haw}^{-1}$ cowanure, respectively).

*** Significant at $\mathrm{p}<0.05$ and $\mathrm{p}<0.01$, respectively. Y: Year, V: Vermicompost, M: Cow manure and $\mathrm{CV}$ : Coefficient of Variation.

\section{Starch and protein content}

The results of the analysis of variance showed that the interaction effect of vermicompost $\times$ cow manure $\times$ year on starch and protein content was significant (Table 5). According to the results, the increase in cow manure and vermicompost rate reduced the grain starch content. The lowest starch contents were obtained from $\mathrm{M}_{2} \mathrm{~V}_{2}$ and $\mathrm{M}_{1} \mathrm{~V}_{2}$. The application of vermicompost also resulted in a significant loss of grain starch so that $\mathrm{M}_{2} \mathrm{~V}_{2}$ reduced it by $3.3 \%$ in the first year and by $7.4 \%$ in the second year versus $\mathrm{M}_{0} \mathrm{~V}_{0}$. Grain protein content was also influenced by cow manure and vermicompost so that they improved grain protein content. When cow manure was applied individually, it did not change protein content significantly, but its incorporation with vermicompost - especially with $10 \mathrm{tha}^{-1}$ vermicompost - was associated with higher protein content of the grains. This effect of vermicompost was stronger in the second year (Table 5). 
Table 5. Mean comparison of cow manure and its vermicompost interaction effect on on starch content, protein content, milling percentage of rice grain.

\begin{tabular}{|c|c|c|c|}
\hline \multirow{2}{*}{$\mathrm{M} \times \mathrm{V}$} & \multicolumn{2}{|r|}{2015} & \multirow[b]{2}{*}{ Milling percent (\%) } \\
\hline & Starch content (\%) & Protein content $(\%)$ & \\
\hline V0M0 & $26.97 \mathrm{c}$ & $6.834 \mathrm{~b}$ & $69.6 \mathrm{~d}$ \\
\hline V0M1 & $27.06 \mathrm{bc}$ & $6.851 \mathrm{~b}$ & $71.3 \mathrm{~cd}$ \\
\hline V0M2 & $27.67 \mathrm{abc}$ & $6.851 \mathrm{~b}$ & $75.7 \mathrm{abc}$ \\
\hline V1M0 & $27.12 \mathrm{abc}$ & $6.834 \mathrm{~b}$ & $71.7 \mathrm{bcd}$ \\
\hline V1M1 & $27.74 \mathrm{ab}$ & $6.852 \mathrm{~b}$ & $76.2 \mathrm{abc}$ \\
\hline V1M2 & $27.70 \mathrm{ab}$ & $6.859 \mathrm{~b}$ & $77.3 \mathrm{ab}$ \\
\hline V2M0 & $27.56 \mathrm{abc}$ & $8.201 \mathrm{a}$ & $77.4 \mathrm{ab}$ \\
\hline V2M1 & $27.81 \mathrm{a}$ & $8.985 \mathrm{a}$ & $77.4 \mathrm{ab}$ \\
\hline V2M2 & $27.83 \mathrm{a}$ & $8.670 \mathrm{a}$ & $78.1 \mathrm{a}$ \\
\hline $\operatorname{LSD}(0.05)$ & 0.717 & 0.969 & 5.78 \\
\hline \multicolumn{4}{|c|}{2016} \\
\hline V0M0 & $26.29 \mathrm{e}$ & $6.88 \mathrm{~b}$ & $65.40 \mathrm{e}$ \\
\hline V0M1 & $26.79 \mathrm{cde}$ & $7.21 \mathrm{~b}$ & $69.99 \mathrm{~cd}$ \\
\hline V0M2 & $26.62 \mathrm{de}$ & $7.33 \mathrm{~b}$ & $70.45 \mathrm{bcd}$ \\
\hline V1M0 & $27.06 \mathrm{~cd}$ & $7.14 \mathrm{~b}$ & $67.22 \mathrm{de}$ \\
\hline V1M1 & $27.30 \mathrm{bc}$ & $8.25 \mathrm{a}$ & $72.14 \mathrm{abc}$ \\
\hline V1M2 & $27.77 \mathrm{ab}$ & $8.61 \mathrm{a}$ & $71.60 \mathrm{abc}$ \\
\hline V2M0 & $27.20 \mathrm{c}$ & $8.65 \mathrm{a}$ & $74.58 \mathrm{ab}$ \\
\hline V2M1 & $28.16 \mathrm{a}$ & $8.56 \mathrm{a}$ & $75.81 \mathrm{a}$ \\
\hline V2M2 & $28.26 \mathrm{a}$ & $8.61 \mathrm{a}$ & $75.92 \mathrm{a}$ \\
\hline $\operatorname{LSD}(0.05)$ & 0.533 & 0.671 & 4.38 \\
\hline \multicolumn{4}{|c|}{$F$ value } \\
\hline $\mathrm{Y} \times \mathrm{M} \times \mathrm{V}$ & $5.84 * *$ & $3.04 *$ & $3.24 *$ \\
\hline $\mathrm{CV}(\%)$ & 1.33 & 6.05 & 4.69 \\
\hline
\end{tabular}

Different letters in the same column indicate significant differences by LSD test $(\mathrm{p}<0.05) .\left(\mathrm{V}_{0}, \mathrm{~V}_{1}\right.$ and $\mathrm{V}_{2}: 0,5$ and $10 \mathrm{t} \mathrm{ha}^{-1}$ vermicompost, respectively; $\mathrm{M}_{0}, \mathrm{M}_{1}$ and $\mathrm{M}_{2}: 0,15$ and $30 \mathrm{t} \mathrm{ha}^{-1}$ cow manure, respectively).

*, ** Significant at $\mathrm{p}<0.05$ and $\mathrm{p}<0.01$, respectively. Y: Year, V: Vermicompost, M: Cow manure and CV: Coefficient of Variation.

\section{Milling percent}

Milling percent was influenced by cow manure $\times$ vermicompost $\times$ year (Table 5 ) so that the application of cow manure and vermicompost increased milling percent in both years. In both years, maximum milling percent was obtained from $\mathrm{M}_{2} \mathrm{~V}_{2}$ and it was $12.21 \%$ higher than the control in the first year and $16.8 \%$ higher in the second year (Table 5).

\section{Discussion}

The reason for difference of mean of treatments between two years was because there was rain in the first year at the time of plant pollination, also at the time duration of seed filling, temperature in the first year was more than that of the second year. Meanwhile, there was cooler temperature in the second year than the first year at the time of plant tiller formation. Thus, there was a difference between the plant reaction to treatments during the first and second years, so the mean of the most characters in first year was less than second year.

Soil fertility plays a prominent role in the improvement of nutrient uptake by rice, whilst soil organic matter is responsible for soil fertility (Zhou et al., 2016). In addition 
to increasing the organic matter, our aim was to improve soil physical and chemical properties.

EC (Electrical conductivity) of vermicompost was higher than farm soil, which may be due to the presence of more salts in the feed of cow. The micronutrients content was significantly higher in vermicomposts than soil but was within permissible limits as recommended by Iran limits of micronutrients in the compost (Sudkolai and Nourbakhsh, 2017). The C:N ratios of the vermicompost was 11.3 that it was in range of a stabilized product for all types of organic manures. It is reported that if $\mathrm{C}: \mathrm{N}$ ratio is $>20$ plants cannot assimilate mineral N (Edwards and Bohlen, 1996) and may affect the growth and yield of rice in field condition.

We observed that applying vermicompost and cow manure can improve the qualitative traits of grains in addition to enhancing NPK uptake and grain yield. Numerous researchers have reported improvement in the growth of the plants in substrates that contain more organic matter. According to Gupta et al. (2014), one consequence of applying organic fertilizer is the reduction of soil $\mathrm{C}: \mathrm{N}$. On the other hand, higher soil organic matter increases the activity of soil microorganisms and improves the availability of nutrients to plants (Srivastava et al., 2010).

In both years at various levels of vermicompost (except $10 \mathrm{t} \mathrm{ha}^{-1}$ in the second year), higher cow manure rate was related to higher total chlorophyll content of leaves. The impact of cow manure and vermicompost on increasing leaf chlorophyll content has been reported for marigold (Gupta et al., 2014) and pak choi (Pant et al., 2009). Vermicompost stimulates plant growth possibly through supplying nutrients and increasing chlorophyll which, consequently, improves photosynthesis or through having such plant growth hormones as auxin and cytokinin (Ievinsh, 2011). Higher chlorophyll content enhances photosynthesis rate and carbohydrate production, which in turn increases 1000-grain weight, spike number per $\mathrm{m}^{2}$, grain number per spike, leaf number per plant, and spike length (Xu et al., 2008; Tejada and González, 2009). Basha et al. (2017) demonstrated that the application of organic matter increased the number of fertile tillers and the number of grains per rice plant. They related higher number of tillers and grains to the influence of vermicompost and green manure on the improvement of PNK uptake. On the other hand, Kumar et al. (2016) related the effect of organic matter on increasing tiller number in rice to the improvement of soil physical features. We also observed the highest number of tillers and grains in plants treated with $5 \mathrm{t} \mathrm{ha}^{-1}$ vermicompost $+20 \mathrm{tha}^{-1}$ cow manure $\left(\mathrm{M}_{2} \mathrm{~V}_{2}\right)$. Cow manure had a negligible impact on the number of tillers and grains per plant when it was applied in the absence of vermicompost, but when it was mixed with vermicompost, the number of tillers was increased by $16-27 \%$ as compared to control in both trial years.

The main grain yield components include the number of tillers, the number of grains per panicle, and grain weight (Zhao and Fitzgerald, 2013). Therefore, any parameter that can improve this component can increase grain yield. Although 1000grain weight was lower in plants fertilized with cow manure and vermicompost, it was offset by the increase in tiller number and grain number per plant. Lower 1000-grain weight in plants treated with cow manure and vermicompost than control may be connected with the inter-grain competition for the uptake of photosynthesis at grain filling phase because when the number of tillers and the number of grains per plant are increased, grains compete more during grain filling period resulting in the loss of their weight (Rusdiansyah and Saleh, 2017). The same fact may be the reason for lower grain starch in plants treated with organic fertilizer as compared to control. Hao et al. 
(2007) reported that grain starch showed a reverse relationship with grain protein and higher $\mathrm{N}$ uptake resulted in the loss of starch reserve. We also observed that the treatment with organic fertilizer increased grain protein content. The impact of vermicompost and cow manure on the improvement of grain protein has been reported by Bejbaruah et al. (2013) and Tejada and González (2009), too. Thus, when plants are not faced with $\mathrm{N}$ uptake constraint, more $\mathrm{N}$ is absorbed and mobilized to grains, resulting in high grain protein content (Bejbaruah et al., 2013). The incorporation of organic matter with soil, especially vermicompost, stimulates the activity of beneficial soil microorganisms and ensures continuous and sustainable supply of mineral nutrients, especially $\mathrm{N}$, to plants. Then, the nutrient availability to roots, soil physical features, and its vital processes are enhanced and the roots are provided with an optimum substrate. Consequently, chlorophyll content is increased and the growth of vegetative parts is induced (Ievinsh, 2011).

Vermicompost contains the nutrients like $\mathrm{P}, \mathrm{K}, \mathrm{Ca}$, and $\mathrm{Mg}$ in a readily available and absorbable form to plants (Gupta et al., 2014; Amanullah, 2016). We observed that P and $\mathrm{K}$ content and uptake were higher in grains of plants treated with cow manure and vermicompost, so that the highest $\mathrm{P}$ and $\mathrm{K}$ content and uptake were obtained from $\mathrm{M}_{2} \mathrm{~V}_{2}$. As well, some researchers have reported that organic matter enhances available $P$ and indirectly hinders the precipitation of phosphate, which is unavailable to plants, in the $\mathrm{pH}$ range of 6-9 (Mkhabela and Warman, 2005).

Antil and Singh (2007) stated higher grain P and K content of rice under organic fertilization. In addition, vermicompost contains a considerable amount of micronutrients (Amanullah, 2016), humic acid (Maji et al., 2017) and growth stimulators like auxins, gibberellins, and cytokinins and phosphate, enzyme, and vitamin dissolving bacteria (Tejada and González, 2009; Liu et al., 2017). These compounds improve leaf area, tiller number and finally, biological yield (Joshi et al., 2015). Our results revealed that $\mathrm{M}_{2} \mathrm{~V}_{2}$ which received the highest amount of cow manure and vermicompost exhibited the maximum biological yield and grain yield. These findings are consistent with Hasanuzzaman et al. (2010) and Bejbaruah et al. (2013). It should be noted that the effect of vermicompost on the improvement of rice grain yield and quality was stronger in the presence of cow manure, i.e. when only 10 $\mathrm{t}$ ha ${ }^{-1}$ vermicompost was applied $\left(\mathrm{V}_{2} \mathrm{M}_{0}\right)$, grain yield was increased at $51 \%$ in the first year and at $55 \%$ in the second year versus control and when vermicompost $+20 \mathrm{tha}^{-1}$ cow manure $\left(\mathrm{V}_{2} \mathrm{M}_{2}\right)$ was applied, grain yield was increased at $32 \%$ in the first year and at $15 \%$ in the second year versus $\mathrm{V}_{2} \mathrm{M}_{0}$. The influence of cow manure on the improvement of nutrient uptake and rice grain yield has been reported by Hasanuzzaman et al. (2010) and Sudarsono et al. (2014).Organic fertilizers increased nutrient uptake and grain protein, resulting in higher milling percentage and grain hardiness so that the highest milling percentage in both years was associated with $\mathrm{M}_{2} \mathrm{~V}_{2}$.

Rice grain milling percentage is one of the major qualitative traits of grain and its loss results in considerable loss of cooking quality and crop price (Ravi et al., 2011; Kumar et al., 2016). Dixit and Gupta (2000) and Yuan et al. (2014) reported milling percentage gain as one effect of organic fertilizers on the quality improvement of rice grains. Davari and Sharma (2010) reported that the integrated application of farmyard manure + vermicompost + plant residue led to the improvement of yield, net profit, and grain quality of basmati rice. 


\section{Conclusion}

The results showed that the mixture of vermicompost and cow manure improved the physical and chemical properties as compared to only cow manure. Applying a mixture of cow manure and vermicompost increased the leaf chlorophyll and NPK uptake by rice. Although the organic fertilizers that were used in this study reduced grain starch content, they resulted in grain yield gain and improved the qualitative traits of grains like the milling percent and protein content. In spite of the fact that cow manure, when applied with vermicompost, enhanced nutrient uptake and grain yield, vermicompost was much more efficient than cow manure. In addition, plots that were fertilized with cow manure had more weeds than those fertilized with vermicompost. Since the soil of most paddy farms are suffering from organic matter deficiency, the application of animal residue as vermicompost can improve their organic matter content and can increase the grain quality and yield. On the other hand, the vermicomposting of animal residue curbs environmental problems and cuts down the cost of weed management of the farm. Although vermicompost is a farm input with high cost for farmers, its cost is offset by grain yield gain and it maintains soil organic content at high levels for several years. Though vermicompost has a high potential to sustain rice production, further research is required to find out the long-term effects of the application of vermicomposts derived from plant and animal residue.

\section{REFERENCES}

[1] Amanullah, H. (2016): Influence of organic and inorganic nitrogen on grain yield and yield components of hybrid rice in Northwestern Pakistan. - Rice Science 23(6): 326333.

[2] Antil, R. S., Singh, M. (2007): Effects of organic manures and fertilizers on organic matter and nutrients status of the soil. - Archive Agronomy and Soil Science 53:519-528.

[3] Arnon, D. I. (1949): Copper enzymes in isolated chloroplasts. Polyphenoloxidase in Beta vulgaris. - Plant Physiology 24 (1):1-15.

[4] Basha. S. J., Basavarajappa, R., Hebsur, N. S. (2017): Nutrient uptake as influenced by organic and inorganic sources of nutrients under aerobic rice cultivation. - Environment and Ecology 35(1B):474-479.

[5] Bejbaruah, R., Sharma, R. C., Banik, P. (2013): Split application of vermicompost to rice (Oryza sativa L.): its effect on productivity, yield components, and $\mathrm{N}$ dynamics. Organic Agriculture 3(2):123-128.

[6] Biswas, S., Hazra, G. C., Purakayastha, T. J., Saha, N., Mitran, T., Roy, S. S., Basak, N., Mandal, B. (2017): Establishment of critical limits of indicators and indices of soil quality in rice-rice cropping systems under different soil orders. - Geoderma 292:34-48.

[7] Bodh, P. C., Rai, J. P. (2015): Agricultural Statistics for 2014. Oxford University Press, New Delhi. - Ministry of Agriculture, GOI.

[8] Davari, M. R., Sharma, S. N. (2010): Effect of different combinations of organic materials and biofertilizers on productivity, grain quality and economics in organic farming of basmati rice (Oryza sativa). - Indian Journal of Agronomy 55(4): 290-294.

[9] Dixit, S., Gupta, B. R. (2000): Effect of farmyard manure chemical and biofertilizers on yield and quality of rice (Oryza sativa L.) and soil properties. - Journal of the Indian Society of Soil Science 48(4):773-780

[10] Dong, W., Zhang, X., Wang, H., Dai, X., Sun, X., Qiu, W., Yang, F. (2012): Effect of different fertilizer application on the soil fertility of paddy soils in red soil region of southern China. - PloS ONE 7(9): e44504. 
[11] Edwards, C. A., Bohlen, P. J. (1996): Biology and ecology of earthworm, 3rd edn. Chapman and Hall, New York.

[12] Emami, A. (1996): Plant analysis methods. - Iranian Plant and Water Research Institute No. 928. (In Farsi).

[13] Guo, H., Yuan, H. L., Geng, B., Liu, X., Zhao, Y. K., Zhu, C. X. (2013): Research progress in resource utilization of cattle manure. - Environmental Science and Technology 36(5): 68e75.

[14] Gupta, R., Yadav, A., Garg, V. K. (2014): Influence of vermicompost application in potting media on growth and flowering of marigold crop. - International Journal of Recycle Organic Waste of Agriculture 3(1): 1-7.

[15] Hao, H. L., Wei, Y. Z., Yang, X. E., Feng, Y., Wu, C. Y. (2007): Effects of different nitrogen fertilizer levels on $\mathrm{Fe}, \mathrm{Mn}, \mathrm{Cu}$ and $\mathrm{Zn}$ concentrations in Shoot and grain quality in rice (Oryza sativa). - Rice Science 14: 289-294.

[16] Hasanuzzaman, M., Ahamed, K. U., Rahmatullah, N. M., Akhter, N., Nahar, K., Rahman, M. L. (2010): Plant growth characters and productivity of wetland rice (Oryza sativa L.) as affected GY application of different manures. - Emirate Journal of Food Agriculture 22(1): 46-58.

[17] Ievinsh, G. (2011): Vermicompost treatment differentially affects seed germination, seedling growth and physiological status of vegetable crop species. - Plant Growth Regulation 65(1): 169-181.

[18] Joshi, R., Singh, J., Vig, A. P. (2015): Vermicompost as an effective organic fertilizer and biocontrol agent: effect on growth, yield. - Reviews in Environmental Science and Bio/Technology 14(1):137-159.

[19] Kumar, A., Kumar, A., Dwivedi, A., Shahi, U. P., Naresh, R. K., Kumar, R. (2016): Evaluation of Different Nutrient Management Options for Soil Properties, Ground Water Quality and Factor Productivity of Basmati Rice (Oryza sativa L.) in Light Textured Soil. - International Journal of Bio-Resource and Stress Management 7 (4): 598-605.

[20] Lalandera, C. H., Komakecha, A. J., Vinneråsa, B. (2015): Vermicomposting as manure management strategy for urban small-holder animal farms - Kampala case study. Waste Management 39: 96-103.

[21] Lazcano, C., Gómez-Brandón, M., Domínguez, J. (2008): Comparison of the effectiveness of composting and vermicomposting for the biological stabilization of cattle manure. - Chemosphere 72(7), 1013-1019.

[22] Liu, Z., Rong, Q., Zhou, W., Liang, G. (2017): Effects of inorganic and organic amendment on soil chemical properties, enzyme activities, microbial community and soil quality in yellow clayey soil. - PloS ONE 12(3): e0172767.

[23] Maji, D., Misra, P., Singh, S., Kalra, A. (2017): Humic acid rich vermicompost promotes plant growth by improving microbial community structure of soil as well as root nodulation and mycorrhizal colonization in the roots of Pisum sativum. - Applied Soil Ecology 110: 97-108.

[24] Meier, S., Curaqueo, G., Khan, N., Bolan, N., Cea, M., Eugenia, G. M., Borie, F. (2017): Chicken-manure-derived biochar reduced bioavailability of copper in a contaminated soil. - Journal of Soils Sediments 17 (3): 741-750.

[25] Mengi, L., Sarkar, N. C., Verma, H., Longkumer, L. T. (2016): Influence of Different Organic Sources of Nutrient on the Productivity of Upland Rice (Oryza sativa L.). International Journal of Bio-Resource and Stress Management 7(3): 450-454.

[26] Mkhabela, M. S., Warman, P. R. (2005): The influence of municipal solid waste compost on yield, soil phosphorus availability and uptake by two vegetable crops grown in a Pugwash sandy loam soil in Nova Scotia. - Agriculture, Ecosystems and Environment 106: 57-67.

[27] Pant, A. P., Radovich, T. J. K., Hue, N. V., Talcott, S. T., Krenek, K. A. (2009): Vermicompost extracts influence growth, mineral nutrients, phytonutrients and antioxidant activity in pak choi (Brassica rapa cv.Bonsai, Chinensis group) grown under 
vermicompost and chemical fertilizer. - Journal Science of Food Agriculture 89: 23832392.

[28] Ravi, U., Menon, L., Anupama, M., Jananni, B. K., Akilandeshwari, M. S. (2011): Analysis of rice grain quality of indigenous organic rice variety-kappakar. - Indian Journal of Agricultural Research 45(2).

[29] Reyes, A. C., Albano, E. L., Briones, V. P., Juliano, B. O. (1965): Varietal differences in physico chemical properties of rice starch and its fraction. - Journal of Agricultural and Food Chemistry 13: 438-442.

[30] Rezaei, H. (2013): A review of research on application of livestock manure in agricultural land of Iran. - Journal of Land Management 1(1): 55-68. (in Farsi)

[31] Rusdiansyah, R., Saleh, M. (2017): Response of two local rice cultivars to different doses of nitrogen fertilizer in two paddy fields. - AGRIVITA, Journal of Agricultural Science 39(2): 137-144.

[32] Srivastava, R., Aragno, M., Sharma, A. K. (2010): Cow dung extract: a medium for the growth of pseudomonads enhancing their efficiency as biofertilizer and biocontrol agent in rice. - Indian journal of microbiology 50(3): 349-354.

[33] Sudarsono, W. A., Melati, M., Aziz, S. A. (2014): Growth and yield of organic rice with cow manure application in the first cropping season. - AGRIVITA, Journal of Agricultural Science 36(1): 19.

[34] Sudkolai, S. T., Nourbakhsh, F. (2017): Urease activity as an index for assessing the maturity of cow manure and wheat residue vermicomposts. - Waste Management.

[35] Tejada, M., González, J. L. (2009): Application of two vermicomposts on a rice crop: effects on soil biological properties and rice quality and yield. - Agronomy journal, 101(2): 336-344.

[36] Toorminaee, V., Allahyari, M. S., Damalas, C. A., Aminpanah, H. (2017): Double cropping in paddy fields of northern Iran: Current trends and determinants of adoption. Land Use Policy 62: 59-67.

[37] Xu, M. G., Li, D. C., Li, J. M., Qin, D. Z., Kazuyuki, Y., Hosen, Y. (2008): Effects of organic manure application with chemical fertilizers on nutrient absorption and yield of rice in Hunan of Southern China. - Agricultural Sciences in China 7(10): 1245-1252.

[38] Yuan, L., Zhang Z. C., Cao, X. C., Zhu, S. C., Zhang, X., Wu, L. (2014): Response of rice production, milled rice quality and soil properties to various nitrogen inputs and rice straw incorporation under continuous plastic film mulching cultivation. - Field Crop Research 155: 164-171.

[39] Zhao, X., Fitzgerald, M. (2013): Climate Change: Implications for the Yield of Edible Rice. - PLOS ONE 8(6): e66218.

[40] Zhou, P., Sheng, H., Li, Y., Tong, C., Ge, T., Wu, J. (2016): Lower C sequestration and N use efficiency by straw incorporation than manure amendment on paddy soils. Agriculture, Ecosystems and Environment 219: 93-100. 